\title{
IFJÚSÁGI SZUBKULTÚRÁK MŰVÉSZETPEDAGÓGIÁJA
}

\section{ART EDUCATION OF YOUTH SUBCULTURES}

\author{
Kárpáti Andrea \\ egyetemi tanár, Budapesti Corvinus Egyetem Társadalomtudományi és Nemzetközi Kapcsolatok Kara \\ andrea.karpati@uni-corvinus.hu
}

\begin{abstract}
ÖSSZEFOGLALÁS
A 20. század a gyermekművész felfedezésével indult, és a kamasz hétköznapi vizuális nyelvének tantervbe emelésével fejeződött be. Ebben az írásban röviden áttekintjük a fiatalok képi nyelve kutatásának irányzatait, amelyek a rajzolástanítástól a művészeti nevelésig, majd a vizuális kultúra oktatásáig vezették el a pedagógusokat. A 21. század a „részvevői kultúra” kora, amelyben az egyre fontosabb közlőnyelvvé váló képi kifejezést világszerte sok millió fiatal már nem az iskolában, hanem informális tanulási környezetekben, egymástól tanulja meg.

Hat ország vizuális nevelési kutatói három kontinensen vizsgálták, hogyan jönnek létre és hogyan működnek a Vizuális Kultúra Tanuló Közösségek, amelyekben a fiatalok az iskolai művészetoktatásra jutó idő sokszorosát töltik anélkül, hogy ennek gyakorlati, továbbtanulási célja lenne. Az írás második felében bemutatjuk, hogyan működik, és miért vonzó ez az alternatív művészetpedagógia, amelyet vizsgálnunk kell, hogy a formális képzés nyithasson értékei és műfajai felé.
\end{abstract}

\section{ABSTRACT}

The $20^{\text {th }}$ century started with the discovery of child art and ended with the integration of the everyday visual language of adolescents into the curriculum. In this paper, we give a brief overview of research trends of the visual competence of children and youth that shifted the focus of art education towards visual culture. The $21^{\text {st }}$ century is characterised by participatory culture, in which young people acquire visual language from each other, through informal learning, and not from their school teachers.

Researchers from six countries studied Visual Culture Learning Communities active on three continents, where young people engage for much more time in art activities, even without the practical purpose of preparing for further studies. In the second part of this paper, we show how these communities function, and why this alterative art training is so popular - in order to support formal education to open up and integrate its values and genres.

Kulcsszavak: vizuális nyelv, vizuális nevelés, ifjúsági szubkultúrák, kollaboratív alkotás, tanulás a társaktól

Keywords: visual language, Art and Design Education, youth subcultures, collaborative creativity, peer learning 


\section{A GYERMEKMŰVÉSZETTŐL A KAMASZOK VIZUÁLIS NYELVÉIG: A KREATIVITÁS FOGALMÁNAK VÁLTOZÁSA A MŰVÉSZETPEDAGÓGIÁBAN}

Homokba húzott vonalak, fakéregre karcolt ábrák, papírhulladékon megörökített formák és figurák: a gyermekek firkái évszázadokon át éppolyan észrevétlenül tüntek el, mint a gügyögve ejtett első szavak vagy az első, bizonytalan lépések. A szerkezeti rajzokat, geometriai ábrákat és díszítő motívumokat, a 19. század végétől kötelező iskolai rajzolástanítás produktumait senki sem őrizte meg, csak a pedagógusképzést segítő gyüjteményekben maradt fenn néhány ilyen alkotás. A rajztanítást (Drawing Studies, Zeichnenunterricht, l'enseignement du dessin) a 20. század első évtizedében váltotta fel a müvészetpedagógia (Art Education, Kunstunterricht, l'enseignement des arts plastiques), s vele a gyerekrajzok gyüjtése és kutatása. John Ruskin múvészeti író, festő és esztéta a 19. század végén, Corrado Ricci, régész és mủvészettörténész a 20 . század első évtizedében fogalmazta meg a később világszerte évtizedekig elfogadott párhuzamot: a gyermekrajz a müvészet történetében a müvészeti stíluskorszakokat ismétli meg. Nemcsak változik, de fejlődik is, egyre közelebb kerül a valóság érzékletes és hüséges megjelenítéséhez (Efland, 2017).

A századfordulón a „gyermekmüvészet” a múzeum falaira került. Franz Cižek például a bécsi Iparmüvészeti Egyetemen, Ebenezer Cooke Londonban, a Királyi Grafikai Társaságban, John Dewey, a 20. századi pedagógiát alapvetően meghatározó, A müvészet mint élmény (Art as Experience, 1935) címü kötetének követői pedig az Amerikai Egyesült Államokban rendezték meg a gyermeki kreativitás ünnepeit. Az 1923-as, mücsarnoki tárlaton, amelyet Nagy László gyermekpszichológus és országos tanfelügyelő, az első magyar nyelvü, empirikus kutatáson alapuló gyermekrajzkönyv szerzője rendezett, az ifjú Yehudi Menuhin hegedült. Egy fiatal lány nyerte a kiállítás aranyérmét, akiből - akárcsak sok ezer rajzversenygyőztesből világszerte - később nem lett jelentős müvész. Az óvodások és kisiskolások „tündéri realista” alkotásait és az idősebbek a felnőtt néző szerint kevésbé vonzó rajzait hamarosan a vizuális képességek kutatói vették vizsgálat alá. A gyermekmüvészet helyett vizuális nyelvről beszéltek, amely magától nem sokáig fejlődik, és tíz-tizenkét éves kor után csak célzott, rendszeres képzéssel fejleszthető (White, 2004).

A gyermekrajzok század eleji kutatóit elsősorban az érdekelte, hogyan rendeződik ,értelmes” (vagyis a felnőttek számára is könnyen azonosítható) jellé az alaktalan firka, hogyan fejlödik az ábrázolás képessége. A gyermekrajzvizsgálat úttöröi csakúgy, mint a legtöbb kortárs rajztantervíró, nem vette figyelembe azt a művészeti forradalmat, amely a század elején zajlott. A kubizmus, konstruktivizmus és szürrealizmus korában, a nonfiguratív és a tudat alatti tartalmakat kifejező mủvek térhódítása idején változatlanul a valósághủ leképezés volt a mérce az iskolában és a kutatólaboratóriumban egyaránt. 
A 20. század ötvenes éveiben Amerikában, a Pennsylvaniai Egyetemen Sigmund Freud tanítványa, egy bécsi pszichológus, Viktor Lowenfeld teremtette meg a vizuális képességek kutatásának első jelentős, a rajztanárképzéshez kötődő mühelyét. A kreatív és kognitív fejlődés párhuzamait mutatta fel, a gondolkodás és a grafikus kifejezőképesség fejlődési párhuzamaira hívta fel a figyelmet. Az érzékelés és ábrázolás két alaptípusát különítette el: a részletformákra ügyelö lineáris és az egészből kiinduló, azt differenciáló haptikus/plasztikus típust. Fejlődési korszak elnevezéseit ma is használják a tanárképzésben, hiszen elsőként érzékeltette a kulturális hatások jelentőségét a fiatalok képi nyelvének alakulásában. A kiskamaszkort a „,bandázás korának” nevezte, és a társak alkotásainak hatására hívta fel a figyelmet, amely vonzóbb és hatásosabb, mint az iskolai képi nyelv. A kamaszkorban elkülönítette az értelmezés korát 12-14 éves kor körül, és a „döntések korát”, 14-17 év között. Az elsőben a valóságmegismerő, realista ábrázolást, a másodikban az egyéni, változatos képi nyelv kialakítását tartotta fontosnak (Lowenfeld, 1949).

A 20. század második felében két, egymással minden részletében ellentétes pedagógiai paradigma határozta meg, hogy mi történt az iskolák rajztermeiben. Az egyik szerint a képi nyelv magától fejlődik: a gyermek alkotónak élményekre és némi technikai segítségre van szüksége csupán, hogy kreativitását kibontakoztathassa. A másik modell szerint a vizuális kultúra bonyolult nyelv, amelynek müfajait és megjelenítési formáit meg kell tanulni, hogy aztán a természettudományos vizualizációtól a müszaki szerkesztésig, az üzleti arculattól a lakberendezésig és a problémamegoldó, terápiás célú alkotásig az élet számos területén felhasználhassuk (Kárpáti-Gaul, 2013). A két célrendszer látszólag nem zárja ki egymást, de a heti 45 perces rajzórákba nem fér el mindkettő. A pedagógusok szakmai elképzelései ezért határozottan kijelölik az egyik vagy másik irányt.

Ami közös a kreativitásfejlesztőkben és a képi nyelv tanítóiban: a készségtárgy státus határozott elutasítása. A gyermekmüvészet kultuszából sajnos visszamaradt egy hamis elképzelés: a velünk született adottságoktól függ, ki milyen szinten képes szabadkézzel papírra rajzolni és festeni. A 20. század végén, amikor már szinte minden, vizuális ábrázolást igénylő szakmában gép segítette a tervezést és megjelenítést, és egyre nagyobb választékban álltak rendelkezésre a tárgyak és eszközök, hogy önmagunkat képekben kifejezhessük, és környezetünket lelkünk hasonlatosságára formáljuk, a vizuális kommunikáció a beszélt és írott nyelvvel egyenrangú közlési forma lett. A századforduló után egyre olcsóbbak lettek a digitális képalkotás eszközei. A fiatalok szívesen és gyakran használták őket, de az iskolában a számítógépek főként a természettudományok és nyelvek elsajátítását szolgálták (Stankewitz, 2009). A pedagógia számos területén már végbement a „vizuális hazatérés” (Nyíri, 2012), de a vizuális nevelés kortárs kultúrára reflektáló, „képi fordulata” még várat magára. 
A 21. század első évtizedére nyilvánvalóvá vált, hogy a vizuális nevelésnek sokkal szorosabban kell kötődnie a mindennapi élethez, mint a müvészeti irányzatokhoz, hiszen nem a mủvészképzést, hanem a korszak domináns közlési formáját kell tanítania. A digitális mủvészeteket magába fogadó vizuális kultúra (Visual Culture) elsőként, az 1980-as években a magyar (!) és az angolszász iskolarendszerben jelent meg. Sem ez az irányzat, sem a német nyelvterületen fontos modellé vált vizuális kommunikáció (Visuelle Kommunikation) néven aktualizált rajzpedagógia nem kapta meg sem a tantervi időt, sem az infrastruktúrát, hogy a felismert igények mentén alakíthassa át programját. A hagyományos keretek között igen nehéz volt új módszerekkel tanítani. A kamaszok ezért alternatív müvészetpedagógiai helyszíneket teremtettek - egymásnak.

\section{VIZUÁLIS KULTÚRA TANULÓKÖZÖSSÉGEK}

A 21. század a „részvevői kultúra” (participation culture) kora, amelyben „a kulturális tevékenységek egyre hozzáférhetőbbek, és a korlátok, melyek a laikust a beavatottól elválasztják, egyre alacsonyabbak. Ez a társadalmi elköteleződés és megosztás kultúrája, amelyben a müalkotások megosztása érdem, és az alkotó folyamat segítése egyfajta informális mentorálás útján magasra értékelt tevékenység. Így terjed a mủvészeti tudás a beavatottaktól a kultúrába újonnan érkezőkig." (Jenkins, 2007, 3.) Napjaink digitális eszköztára jól illeszkedik a közösségi müködéshez, hiszen a megosztás és kommentálás, értékelés és megítélés műveletein alapul. Ez az együttmüködéssel formálódó, képes-szöveges világ alapvetően befolyásolja a fiatalok vizuális nyelvének tartalmát, müfajait, és végső soron újra definiálja ennek fejlődését is. A kulturális antropológiai szemlélet alapján álló kutatók (pl. Shirky, 2010) szerint „stílustörzsek” befolyásolják az ifjúsági kultúrát. Azonos öltözködésü, hasonló zenét és filmet fogyasztó, hasonló szórakozási módokat gyakorló fiatalok összetartó közösségei „termelik ki” a vizuális közléseket - sokkal nagyobb számban, mint valaha.

Hogy megalkothassák saját szubkulturális nyelvüket, a fiataloknak el kell sajátítaniuk a képalkotás technikai és esztétikai alapjait. Úgy tủnik, az új technikákat, müfajokat a leghatékonyabban egymástól tanulhatják meg. A vizuális kultúra tanulóközösségek (VKTK, Visual Culture Learning Communities) olyan területen nyújtanak informális tanulási alkalmat, amelyen az iskola és vidéke nem képes, mert nincs idő, hely és eszköz. Gyakran a szakértelem is hiányzik. Az új képkorszak ifjúsági müfajai nem egy-egy szük közösség furcsa szokásai. Több százezer fiatalról beszélünk országonként, akik hosszú órákat töltenek hetente rajzolással, festéssel, filmezéssel vagy tárgyalkotással. Túlnyomó többségük célja nem az, hogy később ilyen pályára lépjenek. Elkötelezetten tanulnak azért, hogy önmagukat egy olyan képi nyelven fejezzék ki, amely egyszerre közös és 
individuális, könnyen megosztható, de a rejtőzködést is megengedi. A 21. században létrejött egy alternatív müvészetpedagógia, amelyet vizsgálnunk kell, hogy a formális képzés nyithasson értékei és műfajai felé (Freedman et al., 2013).

2009-ben nemzetközi kutatócsoport alakult, amelynek tagjai (az angol Cambridge-i Egyetem, az amerikai Észak-Illinoisi Egyetem, a finn Aalto Egyetem, a holland Amszterdami Egyetem, a kanadai Concordia Egyetem, a tajvani Tajhua [Taihua] Egyetem és az MTA-ELTE Vizuális Kultúra Szakmódszertani Kutatócsoportja munkatársai) hat nagyváros: Amszterdam, Budapest, Chicago, Helsinki, Montreal és Tajpei vizuális tanulóközösségeit kutatják (Kárpáti et al., 2017). A három kontinensen elhelyezkedő, számos gazdasági és kulturális tulajdonságában alapvetően különböző színhelyen az itt felsorolt vizuális alapú szubkultúrák mindegyikét megtaláltuk, országonként sok száz csoporttal, sok ezer taggal:

- cosplay: virtuális és valós találkozásokon alapuló, képregény figuráit életre keltő játék;

- demoscene: müvészi igényü, innovatív számítógépes alkalmazások;

- fanart: rajongói munkák, amelyek a digitális grafika eszközeivel tovább szövik játék- és tévéfilmek és könyvek cselekményét, vagy egyéb módon dolgozzák fel egy népszerü alkotó portréfotóit és mủveit;

- gördeszkás alkotás: deszkák, sporteszközök tervezése, készítése, dekorálása;

- manga és anime: hagyományos és modern japán képregényrajzolás;

- utcamüvészet: poszter-, szórólap-, falikép- és graffitikészítés;

- videoblog és filmszkeccs: rövid, illusztrált előadás, dokumentum-, portré- és művészi film készítése saját és közösségi problémákról.

A nemzetközi mủvészetpedagógiai projekt feladata az új, vizuális alkotó és (egymástól) tanulóközösségek felkutatása, $\mathrm{s}$ a csoportokban dokumentálható pedagógiai elvek és módszerek iskolai alkalmazhatóságának vizsgálata. Országonként két müfajban dolgozó csoportban, 2012-2015 között, mintegy ötven fiatallal készítettünk félig strukturált, fókuszcsoportos interjút, és töltettünk ki a közösség működéséről szóló kérdőívet. A csoportok vezetőivel és a közös munka stílusát meghatározó képviselőivel egyénileg is beszélgettünk. A közösségek legalább tíz foglalkozásán részvevő megfigyelőként voltunk jelen. (A fiatalok igényei szerint segítettünk a szervezésben, alkotásban vagy az elkészült müvek megbeszélésében.) Ebben az írásban a közösségek néhány, pedagógiai szempontból érdekes és értékes jellemzőjét foglalom össze.

A VKTK, mint informális tanulóközösség, az iskolai rendszerhez hasonlóan megbizhatóan, jól szervezett. Ha sikerül helyet találni (az iskolai mühelytöl az üres raktárépületig vagy egy lakóház pincéjéig igen változatosak a helyszínek), a fiatalok rutinosan használják az internetes munkaszervező és képmegosztó alkalmazásokat, hogy a feladataikat felosszák egymás között, és müveiket megosszák 
egy zárt közösség vagy a világ nézőtáborával. Számos nemzeti és nemzetközi találkozási alkalom is van, ahol beszélhetnek a látványokról, amelyeket megalkottak, és játszhatnak például a demoscene vagy cosplay múvekkel.

Míg a középiskolában, a legtöbb országban heti háromnegyed óra jut a vizuális kultúra müvelésére, itt az alkotásra szánható idö rugalmas, mindenki maga dönti el, melyik nap, mennyit képes dolgozni egy-egy filmen, számítógépes programon vagy grafikán. A témák relevánsak, a technikák változatosak. Míg az iskolában anyagok, eszközök és megfelelő helység hiánya miatt - a képzőmüvészetben sok száz éve használatos, alapvető technikákkal lehet megismerkedni, a VKTK-ban mindenki azt tanulhatja, ami az adott müfajban számára a legérdekesebb. A csoportosan híradót készítők a világosítást és a vágást is elsajátíthatják, nemcsak a filmezést. A fanartistok megismerhetik azokat a grafikai technikákat, amelyekkel hüen visszaadhatják rajongásuk tárgyát, a népszerü sorozathőst (KárpátiPapp, 2013).

A stílus a csoporttag szabad döntése. Hat rá, amit és ahogyan a többiek alkotnak, de semmi sem kötelező. Nem úgy, mint az iskolában: sokan beszámoltak arról, hogy a tanárok megtiltották a képregénystílusok utánzását, vagy kigúnyolták a cosplay-játékra készített ruhákat. A VKTK-tagok úgy vélik, a másolással sokat tanulnak egy-egy jellegzetes képi világról, és az irodalmi alkotásokon alapuló kosztümök tervezése és varrása éppolyan képességeket mozgat meg, mint egy „normális” öltözék elkészítése. Egymás értékelése persze gyakran ugyanolyan bántó, mint egy felnőtt kritikája, de itt van idő alaposan megbeszélni, mit kívánt kifejezni az alkotó, és mit lát, vagy éppen mit nem tart jól érzékelhetőnek a témákat, formákat kiválóan értő közönség: a kortárs csoport. Előfordulnak természetesen itt is félreértések, feloldhatatlan ellenérzések, de a csoportból kiválás és új közösség keresése összehasonlíthatatlanul könnyebb, mint egy iskolaváltás vagy tanárcsere.

Az egyéni és társadalmi problémák szimbolikus megjelenitése az egyik legfőbb motiváció, amely a csoporttagokat a VKTK-ba vonzza. A hagyományos rajztantervekben ma is az akadémiai felvételiken elöírt „vizuális problémák” dominálnak: bonyolult fény-árnyék jelenségek visszaadása, arányhü leképezés, illúziókeltő térmegjelenítés. A fiatalokat ugyanakkor a narratívák inspirálják: a belső és a külvilágban zajló küzdelmek, kirekesztettség és elfogadás, szeretet és gyülölet. Bár gyakori téma a közösségekben egy-egy esemény, természeti jelenség vagy irodalmi, filmes mủalkotás feldolgozása is, a szimbolizáció: a valóság tömör, jelzésekben, jelképekben visszaadott képe vonzó, bár igen nehéz, ezért a vizuális kommunikáció minél alaposabb elsajátítására sarkalló feladat (KárpátiSimon, 2014).

Az elkötelezödés meglepően hosszú távú, és a szabadidöre, önkéntes, másokat segítő munkára, saját pénz és eszközök megosztására is kiterjed. A vizsgált csoporttagok háromnegyed része két éve vagy még hosszabb ideje foglalkozik 
a vizuális müfajjal, amelyet ideális önkifejezési formának tekint. A csoportok harmada a törzsgárda, a hetente többször visszatérők csoportja, további harmada egy-két hetente jelentkezik, és vannak az időnként feltủnők, a néhány hetes, intenzív alkotás és beszélgetés (egyfajta rövid, amatőr művészetterápia) után hoszszabb szünetet tartó tagok.

Az alkotások legtöbbje közösségi jellegü. A kultúraközvetítésre szakosodott, informális csoportok között vannak „örökségátadók” (heritage communities), melyek saját múltjukhoz való kötődésüknek és az ebben gyökerező identitásuknak adnak képi kifejezést, illetve a közös érdeklődési területen szervezett közösségek (interest communities), melyek egy, mások által már gyakorolt műfaj gyakorlására szövetkeznek. Ez utóbbiak számára a közösséghez való tartozás gyakran a mindennapi életből való időleges, de annál kellemesebb kiszakadás lehetöségét is jelenti. Míg az örökségátadók gyakran egy életen át müködnek mint szabadidős alkotók, az érdeklődési csoportok addig élnek, amíg a szubkultúra vonzóereje fogva tartja a tagokat (Freedman, 2006). A digitális kultúrában a kollaboratív alkotás új formái nyernek polgárjogot: például az „újrakeverés” (remix), amely egy kész mủ (például egy film előzetese) újravágását vagy más hanggal társítását is jelentheti. A filmes és állóképi idézet és adaptáció a plágium köréből kikerülve, elfogadott alkotói módszer lett, sőt, hidat képez a hivatásos és mükedvelő alkotók között.

A VKTK-ban, hasonlóan a felnőtt tudásépítő közösségekhez, egymás tanitása természetes és önzetlen. „A megértés élménye és a tudás új formái a társadalmi környezetből eredeztethetők. A tudás itt nem egy birtokba vehető objektum, hanem egy tevékenység, amelyben mindenki részesülhet." (Sefton-Green-Soep, 2007, 847.) A csoportokban nincs rendszeresen jelen lévő felnőtt oktató, de ez nem jelenti a tapasztalt szakértő elutasítását. A társadalmi hálózatokon keresztül könnyebb lett a tanácskérés, a digitális technológiák pedig számos vizuális területen teszik képessé az amatöröket arra, hogy ötleteiket az internetes segédletek alapján, professzionális módon valósíthassák meg (Shirky, 2010). Mindez természetesen nem jelenti a formális képzés jelentőségének csökkenését, sőt: a gáttalanul áradó képi kavalkádban a jobban felkészültek előnye nyilvánvaló. A VKTK-k vonzereje éppen a tanulási lehetőségekben rejlik: a társak egymást segítve jutnak előre, s útjuk visszavezethet a formális képzésbe is.

Mit tanulhat a vizuális nevelés a képi nyelv elsajátítását célul tűző, informális csoportoktól? Mi az, ami a heti egy vagy két, 45 perces órán is megvalósítható? A holland rajztanterv példája mutatja, hogy a társadalmilag érzékeny témák, a csoportos alkotás, a kortárs képzőművészet és médiakultúra integrálása ilyen keretek között is lehetséges (Lanschot Hubrecht-Nieveen, 2018). Az iskola otthont adhat azoknak az alkotó közösségeknek, amelyeknek stílusával, céljaival, müködésmódjával azonosulni tud, s ezzel gazdagíthatja múvészeti kínálatát és pedagógiai kultúráját (Kárpáti-Papp, 2013). A tanárok részvevő megfigyelö- 
ként megismerhetik a kamaszok (képi) világát, és mentor szerepben, mélyebb és változatosabb kapcsolatba kerülhetnek a területükhöz erősen kötődö ifjú alkotókkal. A formális és informális tanulási környezet ezzel összeér, a kortárs müvészet és a mindennapi vizuális kultúra több teret nyerve, természetesen összekapcsolódhat.

Ezt a kapcsolatteremtést segíti az MTA-ELTE Vizuális Kultúra Szakmódszertani Kutatócsoportja is, amelynek 2016-2020 között készülö, alternatív tantervi moduljai a 21. század képi nyelvét egy-egy területre: a vizuális kommunikációra, médiára, környezetkultúrára és a kortárs képzőmüvészetre fókuszálva tanítják. Nem kívánják átadni a képzőmúvészet, tárgykultúra és építészet teljességét, inkább az elmélyülést segítik a vizuális kultúra egy-egy müfajában. Sok csoportos alkotó módszert használunk, hiszen a kortárs vizuális kultúra is így alakul. Célunk, hogy a képi nyelv iránt érdeklődők az iskolában is megtalálják vagy kialakíthassák tanulóközösségüket.

\section{KÖSZÖNETNYILVÁNÍTÁS}

A közlemény alapját képző kutatás az MTA-ELTE Vizuális Kultúra Szakmódszertani Kutatócsoport, „Moholy-Nagy Vizuális Modulok - a 21. század képi nyelvének tanítása" projekthez kapcsolódik. A kutatást a Magyar Tudományos Akadémia Tantárgypedagógiai Kutatási Programja támogatja.

\section{IRODALOM}

Dewey, J. (1934): Art as Experience. Rahway, NJ: The Barnes Foundation Press

Efland, A. (2017): A History of Art Education: Intellectual and Social Currents in Teaching the Visual Arts. Boston: Teachers' College Press

Freedman, K. (2006): Adolescents, Identity, and Visual Community: The Formation of Student Communities Based on Popular Visual Culture. Visual Arts Research, 32, 2, 26-27.

Freedman, K. - Hejnen, E. - Kallio-Tavin, M. et al. (2013): Visual Culture Learning Communities: How and What Students Come to Know in Informal Art Groups. Studies in Art Education, 54, $2,103-115$.

Jenkins, H. (2007): Confronting the Challenges of Participatory Culture: Media Education for the $21^{\text {st }}$ Century. Cambridge, MA: MIT Press

Kárpáti A. (2004): A kamaszok vizuális nyelve. Budapest: Akadémiai Kiadó

Kárpáti A. - Freedman, K. - Heijnen, E. et al. (2017): Collaboration in Visual Culture Learning Communities: Towards a Synergy of Individual and Collective Creative Practice. International Journal of Art \& Design Education, 36, 2, 164-175. DOI: 10.1111 jade.12099.

Kárpáti A. - Gaul, E. (eds.) (2013): From Child Art to Visual Language of Youth. New Models and Tools For Assessment of Learning and Creation in Art Education. Bristol: Intellect Publishers 
Kárpáti A. - Papp L. (2013): Vizuális tanuló közösségek. In: Benedek A. - Tóth P. (szerk.): Új kutatások a neveléstudományokban 2012. A munka és a nevelés világa a tudományban. Budapest: Eötvös Kiadó, 61-78.

Kárpáti A. - Simon T. (2014): Symbolisation in Child Art - Creation and Interpretation of Visual Metaphors. In: Benedek A. - Nyíri K. (eds.): The Power of the Image. Emotion, Expression, Explanation. Frankfurt/M.: Peter Lang Verlag, 143-160.

Lanschot Hubrecht, V. - Nieveen, N. (2018): Napjaink hollandiai mủvészeti nevelése: kié a tanterv? Magyar Tudomány, 6, https://mersz.hu/hivatkozas/matud_f8105\#matud_f8105

Lowenfeld, V. (1949): Creative and Mental Growth. Berkeley: University of California Press

Nyíri K. (2012): Vizuális hazatérés - a neveléstudomány képi fordulata. In: Benedek A. (szerk.) (2012): Digitális pedagógia - Tanulás IKT környezetben. Budapest: Typotex Kiadó, https:// www.tankonyvtar.hu/hu/tartalom/tamop412A/2011-0023 DP/dp5_2_vizhaza_ch000000.html

Sefton-Green, J. - Soep, E. (2007): Creative Media Cultures: Making and Learning Beyond the School. In: Bresler, L. (ed.) (2007): International Handbook of Research In Arts Education. Dordrecht: Springer, 835-854.

Shirky, C. (2010). Cognitive Surplus: Creativity and Generosity in a Connected Age. New YorkLondon: Penguin Press

Stankewitz, M. (2009): Constructing an International History of Art Education: Periods, Patterns and Principles. The International Journal of Arts Education, 7, 1, 4-20. http://maryannstankiewicz.com/wordpress/wp-content/uploads/2010/04/Constructing-International-History-of-Art-Education.pdf

White, J. H. (2004): $20^{\text {th }}$ Century Art Education: A Historical Perspective. In: Eisner, E. - Day, M. (2004) (eds.): Handbook of Research and Policy in Art Education. London: Routledge, 55-84. 